\title{
Performance Appraisal of Asset Management Companies in Bangladesh
}

\author{
Avijit Mallik ${ }^{1}$, Saad Niamatullah $^{2} \&$ Swarup Saha ${ }^{1}$ \\ ${ }^{1}$ Lecturer, Institute of Business Administration, University of Dhaka, Dhaka, Bangladesh \\ ${ }^{2}$ Post Graduate Student, Institute of Business Administration, University of Dhaka, Dhaka, Bangladesh \\ Correspondence: Avijit Mallik, Institute of Business Administration, University of Dhaka, Dhaka-1000, \\ Bangladesh. Tel: 88-02-966-1900. E-mail: avijit@iba-du.edu
}

Received: May 8, 2019

Accepted: June 22, 2019

Online Published: June 30, 2019

doi:10.5539/ijef.v11n8p53

URL: https://doi.org/10.5539/ijef.v11n8p53

\begin{abstract}
Mutual funds are a type of collective investment scheme where a large number of small investors pool their savings together and entrust it to an asset manager, who manages the capital to maximize returns in exchange for a management fee. While mutual funds and other collective investment schemes are popular in developed markets, with assets under management (AUM) to GDP ratio of 62\% globally, they are yet to gain popularity in Bangladesh, where AUM-to-GDP ratio stands at only $0.53 \%$. However, mutual funds and asset management companies have been growing at high rates, with 37 closed-end and 42 open-end funds now in operation, and there is enormous potential for growth in the mutual fund industry in Bangladesh. Since mutual funds are a new product in the Bangladeshi market, a detailed study was performed in order to distinguish skilled asset managers from unskilled asset managers. In this study, "skill" has been defined as the ability to beat the broad-market DSEX index on after-fee basis, with the underlying logic that managers - all of whom charge a management fee should at least be able to beat a passive investment in the broad DSEX. For purposes of the study, the weekly NAV at market value was of 76 mutual funds managed by 16 asset management companies (AMCs) were collected. The weekly returns for the DSEX and each fund under consideration were calculated separately. Four well-known measures were used to rank each mutual fund utilizing the weekly returns. The measures were Jensen's Alpha, the Sharpe Ratio, the Treynor Ratio and the Modigliani M2 Alpha ratio. For AMCs managing multiple funds, the measures were asset-weighted to calculate the measure for the AMC as a whole. Our findings illustrated that only 5 out of 16 AMCs managed to beat the DSEX index and earn an alpha over the benchmark. Our findings were in line with academic consensus which states that active management is a zero-sum game and that the majority of actively managed funds will underperform the index on an after-fee basis. Our recommendation is for AMCs to introduce passively-managed index funds which will at least keep up with the market return and minimize fees and trading costs.
\end{abstract}

Keywords: mutual funds, mutual funds in bangladesh, asset management, asset management companies, mutual fund performance

\section{Introduction}

Mutual Funds are a certain type of collective investment scheme, in which savings from a large number of investors are pooled together and placed under management of an asset manager. The asset manager is charged with the responsibility to manage the pool of capital efficiently to garner a return on the invested capital, in return for a management fee. The investors benefit from the professional expertise and skills of the fund manager, who manages the fund on behalf of the investors and aims to earn a positive return on the investors' funds. In exchange, the fund manager is entitled to charge a fee for managing the funds.

The first Mutual Fund in Bangladesh was the "First ICB Mutual Fund" which was launched in 1980. It was launched by the Investment Corporation of Bangladesh (ICB), a state-owned financial corporation. The first private asset management company to launch in Bangladesh was AIMS, which started its journey in 1999. In 2001, the Securities and Exchange Commission of Bangladesh formulated the Bangladesh Securities and Exchange Commission (Mutual Fund) rules, 2001 which remain the main law regulating mutual funds in Bangladesh. A wave of new asset management companies came to the scene after 2009, led by RACE Asset Management and LR Global Asset Management Company; they mostly focused on launching closed-end mutual 
funds. The mutual fund industry, though still at a nascent stage, has continued grown steadily and a total of 32 Asset Management Companies are registered with the SEC at present, which together manage a total of 37 closed-end and 42 open-end mutual funds.

\section{Research Objective and Methodology}

\subsection{Objective}

In Bangladesh, the amount of investment in mutual fund is very low in comparison with the global ratio. There are couple of factors that lead to this aversion of investors. However, if properly managed and investor confidence can be built up, there is a huge scope for this market to flourish. A good number of studies have been conducted till now in different countries to measure the performance of the mutual funds. The objective of this study is to carry out a quantitative evaluation of the returns generated by Asset Management Companies of Bangladesh, in order to be able to appraise the performance of each company and to find out the relative degree of skill (or lack thereof) of each asset management company compared to others and the industry as a whole. In our study, "skill" is defined simply as the ability to beat the market index. As a result, any asset management company which has positive alpha is defined to be "skilled" and any asset management company which has negative alpha is defined as "unskilled".

\subsection{Methodology}

This paper is prepared on the basis of primary data collected from the financial statements of the asset management companies being studied, and weekly Net Asset Value (NAV) data from the Dhaka Stock Exchange. The weekly NAV data of all closed-end and open-end mutual funds with an operational history of at least 1 year was collected for purposes of this study.

The DSEX is a float-adjusted market-cap weighted index of all stocks trading on the DSE subject to a minimum market cap and liquidity requirement. The DSEX index was chosen as the benchmark for calculation of the funds' alpha, as it best represented the investment styles of the mutual funds.

The population for this study is 37 closed end mutual funds and 39 open ended mutual funds in Bangladesh. For our analysis we have analysed a sample of 16 firms which are in operation for more than 1 year.

In our study, performance of these mutual funds was measured by 4 different measures, namely: Jensen's Alpha, Sharpe ratio, Treynor ratio and M2 Alpha. The measures are applicable for each fund managed by the Asset Management Companies. In order to judge the skill of the Asset Management Company as a whole, a weighted average was calculated based on the total net asset value of the funds managed by the Asset Management Companies. Then judgement was applied to rank the relative importance of each measure to judge the overall skill of the asset manager, and finally the Asset Management Companies were ranked according to their skill.

\section{Literature Review}

Mutual Fund Performance Evaluation is an oft-studied topic in developed countries, where the concept of mutual funds has a long history.

Sharpe (1966) in his seminal paper studied the performance of mutual funds. Drawing on research by Treynor (1965) he was one of the first to suggest that the expected risk of mutual funds should be taken into account in addition to expected performance as measured by arithmetic or geometric return. Sharpe recognized that different portfolios may display various degrees of variability of return while having roughly the same rate of return, or that portfolios which exhibited similar degrees of variability of return may have different rates of return. Sharpe concluded that the incremental return over the incremental risk added was a useful indicator of portfolio manager efficiency. Sharpe introduced a measure, which he called the "Reward-to-variability ratio" or $(\mathrm{R} / \mathrm{V})$, which is commonly known today as the Sharpe Ratio, to rank mutual funds existing in the US back then according to their excess return relative to risk.

Treynor (1966) tackled the question of whether mutual funds can outguess the market. In an efficient market, all publicly available information is already factored in asset prices and a manager cannot earn a return in excess of the market return by security selection. Treynor recognized that there was a hindsight bias when it was claimed that the market was obviously overvalued in 1929 and obviously undervalued in the 1950's, and set about to test whether mutual fund managers should have been able to predict the market crash in 1929 or the period of strong performance subsequent to the 1950 's. Annual Mutual fund performance was widely available at that time and Treynor chose 57 open-end mutual funds to test the hypothesis of whether mutual fund managers can outguess the market. Treynor hypothesized that skilled mutual fund managers would be able to correctly anticipate broad market moves, and thus alter their sector allocation between stocks and bonds depending upon their prediction of 
whether markets were going to rise or fall.

Ferreira et al. (2013) analyzed the performance of open-end actively managed equity mutual funds in 27 countries and revealed that mutual funds' performance is affected by country characteristics i.e. funds in countries with liquid stock market and strong legal institution perform better. Grinblatt and Titman (1994) found a significant positive relationship between turnover and fund manager's ability to obtain abnormal return.

Brinson et al. (1995) tested the influence of investment policy, market timing, and security or manager selection on total portfolio return and concluded that total return is more affected by investment policy decision than by active management. After checking the performance persistence of Chinese equity funds Rao et al. (2017) spotted positive association of fund size, expense ratio and age with the performance of the funds. However, they found that like developed markets, Chinese equity funds don't show consistency, i.e. funds that provided higher return in the previous year don't continue to provide greater return in the following year. Further they commented that equity funds in emerging market perform better than those of developed market. On the other hand, to test the Tunisian equity mutual fund performance, Belgacem and Hellara (2011) found that past performance and fund size have significantly positive influence on the fund's future performance. Hou (2012) examined 200 domestic equity mutual funds in Taiwan and had a similar finding i.e. well-performing (poorly-performing) funds of previous year keep-on performing well (performing poor) in the following year.

Kaur (2018) tested the behavior of Indian mutual fund investor and found that knowledge and risk perception affect the choice of mutual funds. Therefore, the author suggested to emphasis on enhancing the knowledge of investors which will lead to an investor driven industry. Sharma and Paul (2015) studied the performance of mutual funds in India and identified no persistency in performance over time. Additionally the authors suggested that mutual funds can be an appropriate option for highly risk averse investors.

Hili et al. (2016) showed that large-sized equity portfolios lead over the small and medium-sized portfolios. This findings again indicates that fund size is an important determinants of performance. Using quarterly data for a prolonged period (1991-2012) Champagne et al. (2018) suggested a new measure for portfolio activity namely, the modified turnover which represents the changed portion of the portfolio from one quarter to the next. The authors also found that volatility, flows, size, number of stocks, and the expense ratio are important factors of modified turnover.

Nguyen et al. (2018) revealed that mutual funds returns are correlated with investor confidence, fund size, turnover, expense, liquidity, performance persistence and the age of funds.

Apap and Collins (1994) scanned the returns of fifteen internationally diversified mutual funds and commented that the funds' performance is mostly likely driven by the benefits of diversification. Cheney et al. (1992) also mentioned that internationally diversified portfolio of securities would be less volatile than fully domestic portfolio. Kiymaz (2015) checked the performance of Chinese mutual funds for the period January 2000 to July 2013, and found that older funds, funds with higher fees, high price to book ratio and smaller funds perform better than others.

\section{Analysis and Findings}

There are a total of 37 closed end mutual funds and 39 open ended mutual funds in Bangladesh. The weekly NAV at market value was collected for each of the 76 mutual funds were collected. A total of 16 Asset Management Companies were included in the analysis. Asset Management Companies with an operating history of less than 1 year were excluded. The weekly returns for the DSEX and each fund under consideration were separately calculated. Four well-known measures were used to rank each mutual fund utilizing the weekly returns. The measures were Jensen's Alpha, the Sharpe Ratio, the Treynor Ratio and the Modigliani M2 Alpha ratio. A single Asset Management Companies may manage a large number of funds. To combine the results for single funds into a measure for the Asset Management Company as a whole, a weighted average of the measure for each fund was calculated, based on the latest net asset value at market price of the fund in BDT. A final measure was calculated for each company by taking a simple average of the four measures, and a final ranking was performed based on that measure.

The variables used to quantify the performance of the asset managers are explained below, followed by the findings and analysis.

Jensen's Alpha: The Jensen's measure, also called Jensen's Alpha, is a risk-adjusted performance measure that represents the average return on a portfolio or investment relative to that predicted by the capital asset pricing model (CAPM), given the portfolio's or investment's beta and the average market return. The Jensen's Alpha measures portfolio risk by its Beta, or how much systematic risk has been taken. It does not consider 
non-systematic risk.

M2 Alpha: The M2 Alpha is a measure of the risk-adjusted returns of an investment portfolio. M2 Alpha measures the returns of the portfolio, adjusted for the risk of the portfolio relative to that of some benchmark, which is usually a market benchmark. It is derived from the Sharpe ratio, which is widely used, but it in the form of a percentage return, which is a significant advantage as it makes it dramatically more intuitive for investors to interpret. Although the M2 Alpha and Jensen's Alpha are both measures of risk-adjusted return, it should be kept in mind that Jensen's Alpha measures portfolio risk by its Beta, while the M2 Alpha measures portfolio risk by its standard deviation. Therefore Jensen's Alpha considers only systematic risk while M2 Alpha considers total (systematic + unsystematic) risk.

Sharpe Ratio: The Sharpe ratio is the average percentage return earned in excess of the risk-free rate per unit of volatility (usually measured as standard deviation) or total risk. The performance associated with risk-taking activities can be isolated by subtracting the risk-free return. One intuition of this calculation is that a portfolio engaging in riskless investment, such as the purchase of government treasury bills (for which the expected return is the risk-free rate), has a Sharpe ratio of exactly zero. Generally, an investment is more attractive the the greater the value of the Sharpe ratio. The Sharpe ratio calculates risk on the basis of standard deviation, thus taking into account total (systematic + non-systematic) risk.

Treynor Ratio: The Treynor ratio is also called the Treynor measure or reward-to-volatility ratio and is named after Jack L. Treynor. It is a measurement of the excess returns earned relative to a risk-free investment (e.g., Treasury bill), per unit of market risk assumed. The market risk is measured by the beta of the portfolio. The Treynor ratio relates excess return over the risk-free rate to the additional risk taken. In contrast to Sharpe ratio, systematic risk is used instead of total risk. The higher the Treynor ratio, the better the performance of the portfolio under analysis.

Table 1. AMCs ranked according to Jensen's Alpha

\begin{tabular}{llc}
\hline Ranking & Company & Jensen's Alpha \\
\hline 1 & Impress Capital & $9.72 \%$ \\
2 & VIPB & $8.10 \%$ \\
3 & Peninsula & $5.60 \%$ \\
4 & AT Capital & $4.34 \%$ \\
5 & AIMS & $3.27 \%$ \\
6 & LR Global & $0.01 \%$ \\
7 & CAPM & $-0.70 \%$ \\
8 & RACE Asset Management & $-1.18 \%$ \\
9 & UFS & $-2.05 \%$ \\
10 & ICB AMCL & $-2.36 \%$ \\
11 & LankaBangla & $-3.29 \%$ \\
12 & SEML & $-3.67 \%$ \\
13 & Vanguard AMC & $-4.34 \%$ \\
14 & Alliance Capital & $-4.35 \%$ \\
15 & Prime Finance & $-8.36 \%$ \\
16 & Alif & $-13.30 \%$ \\
\hline
\end{tabular}

Ranking Asset Managers by Jensen's Alpha suggested that out of the 16 Asset Management Companies under consideration, only 6 managed to beat the market, while the rest of the 10 companies underperformed the market. Fund managed by Impress Capital had the most impressive results, followed by VIPB and Peninsula. The alphas ranged from $+9.72 \%$ per year to $-13.30 \%$ per year. However it should be noted that both the top-scoring and bottom-scoring companies are quite new and a few more years of operational history are required to get a more accurate view. 
Table 2. AMCs ranked according to M2 Alpha

\begin{tabular}{llc}
\hline Ranking & Company & $\mathrm{M}^{2}$ Alpha \\
\hline 1 & VIPB & $12.19 \%$ \\
2 & Impress Capital & $10.89 \%$ \\
3 & AIMS & $5.41 \%$ \\
4 & Peninsula & $5.05 \%$ \\
5 & AT Capital & $4.83 \%$ \\
6 & Vanguard AMC & $-0.65 \%$ \\
7 & CAPM & $-0.72 \%$ \\
8 & LR Global & $-1.01 \%$ \\
9 & LankaBangla & $-1.73 \%$ \\
10 & UFS & $-1.87 \%$ \\
11 & SEML & $-2.09 \%$ \\
12 & Alliance Capital & $-2.52 \%$ \\
13 & RACE Asset Management & $-2.52 \%$ \\
14 & Prime Finance & $-6.27 \%$ \\
15 & ICB AMCL & $-7.93 \%$ \\
16 & Alif & $-9.73 \%$ \\
\hline
\end{tabular}

Only 5 Asset Management Companies outperformed the market using the M2 Alpha measure. The top performing companies remained mostly unchanged, but the order has shifted somewhat. This is due to different levels of systematic and non-systematic risk undertaken by the companies. The realized performance shows a wide divergence, from $12.19 \%$ to negative $9.73 \%$.

Table 3. AMCs ranked according to Sharpe Ratio

\begin{tabular}{llc}
\hline Ranking & Company & Sharpe Ratio \\
\hline 1 & Impress Capital & 0.1323 \\
2 & VIPB & 0.1162 \\
3 & Peninsula & 0.0611 \\
4 & AT Capital & 0.0476 \\
5 & AIMS & 0.0276 \\
6 & ICB AMCL & -0.0008 \\
7 & LR Global & -0.0064 \\
8 & CAPM & -0.0067 \\
9 & Vanguard AMC & -0.007 \\
10 & RACE Asset Management & -0.0142 \\
11 & LankaBangla & -0.0208 \\
12 & UFS & -0.0226 \\
13 & SEML & -0.0234 \\
14 & Alliance Capital & -0.0307 \\
15 & Prime Finance & -0.082 \\
16 & Alif & -0.1187 \\
\hline
\end{tabular}

A ranking by Sharpe ratio shows the order of Asset Management Companies are largely unchanged from ratings shown earlier. This is not surprising because all measures use the same risk and return figures for calculations. A total of five companies beat the risk free rate, however, this could have been caused by the measurement period for the funds including the 2010 stock market crash. Both the top and bottom ranked companies are quite new and a few more years of operational results ought to be considered before coming to a conclusion of their skills. 
Table 4. AMCs ranked according to Treynor Ratio

\begin{tabular}{llc}
\hline Ranking & Company & Treynor Ratio \\
\hline 1 & Impress Capital & 0.0332 \\
2 & AT Capital & 0.0147 \\
3 & VIPB & 0.0134 \\
4 & Peninsula & 0.0102 \\
5 & ICB AMCL & 0.008 \\
6 & UFS & 0.0073 \\
7 & AIMS & 0.003 \\
8 & Vanguard AMC & -0.0003 \\
9 & LR Global & -0.0004 \\
10 & Prime Finance & -0.0004 \\
11 & RACE Asset Management & -0.0011 \\
12 & SEML & -0.0012 \\
13 & LankaBangla & -0.0019 \\
14 & Alliance Capital & -0.0024 \\
15 & CAPM & -0.0112 \\
16 & Alif & -0.0264 \\
\hline
\end{tabular}

The ranking shows that seven companies managed to beat the risk free rate. Like the previous measure, this could likely have been caused by the measurement period for the funds falling during the stock market crash in 2010. Other than the small number of funds achieving a positive excess return, the order of the asset management companies remain largely unchanged.

In order to come to our final combined ranking, the ranks of each company for each measure were combined by simple summation, and the companies ranked from the lowest combined ranking to the highest. The combined ranking of the companies are as follows:

Table 5. Overall ranking of asset management companies

\begin{tabular}{clccccc}
\hline Ranking & Company & Jensen's Alpha & M $^{2}$ Alpha & Sharpe Ratio & Treynor Ratio & Combined Score \\
\hline 1 & Impress Capital & 1 & 2 & 1 & 1 & 5 \\
2 & VIPB & 2 & 1 & 2 & 3 & 8 \\
3 & Peninsula & 3 & 4 & 3 & 4 & 14 \\
4 & AT Capital & 4 & 5 & 4 & 2 & 15 \\
5 & AIMS & 5 & 3 & 5 & 7 & 20 \\
6 & LR Global & 6 & 8 & 7 & 9 & 30 \\
7 & ICB AMCL & 10 & 15 & 6 & 5 & 36 \\
8 & Vanguard AMC & 13 & 6 & 9 & 8 & 36 \\
9 & CAPM & 7 & 7 & 8 & 15 & 37 \\
10 & UFS & 9 & 10 & 12 & 6 & 37 \\
11 & RACE Asset Management & 8 & 13 & 10 & 11 & 42 \\
12 & LankaBangla AMCL & 11 & 9 & 11 & 13 & 44 \\
13 & SEML & 12 & 11 & 13 & 12 & 48 \\
14 & Alliance Capital & 14 & 12 & 14 & 14 & 54 \\
15 & Prime Finance & 15 & 14 & 15 & 10 & 54 \\
16 & Alif & 16 & 16 & 16 & 16 & 64 \\
\hline
\end{tabular}

In our final ranking, Impress Capital, VIPB, Peninsula and Asian Tiger Capital Partners come out as the most likely skilled asset management companies considering all of the funds under their management. On the other hand, Alif and Prime Finance come at the bottom of most performance measures.

It should be kept in mind that a more rigorous scientific analysis is required before any asset management company can be said to be "skilled" or "unskilled". The analysis done in this report did not take into account the operational history of the asset management companies, which would be required for a scientific analysis. No confidence bands were constructed to find out the significance of the measures either, which is the scientifically 
correct way to determine whether a manager can be said to be "skilled" or "un-skilled". Finally, as market behavior evolves, managers who once show signs of outperformance can fall behind the market, and vice versa.

A few notable exceptions are seen, most notably, VIPB asset management, which both has a long operating history and also manages to reliably beat the market. It should be kept in mind that since the operating history of mutual funds in Bangladesh is relatively short, a few factors could have affected the results. Most notably, a stock market bubble and subsequent crash in the 2010-2011 period is likely to have severely depressed the performance figures of the funds in existence at that time. At the same time, the Bangladesh Securities and Exchange Commission enforces a rule that makes it compulsory for mutual funds to have $60 \%$ of their assets invested in capital market securities at all times, which is a constraint that prevents mutual fund managers from minimizing their exposure during market downturns, as occurred in 2010-2011. The stock market witnessed a bull run during the year of 2017, which may have biased the performance figures of the funds launched at the beginning of the period upward.

\section{Conclusion}

To conclude, the results of our study are broadly in line with the Efficient Market Hypothesis (EMH), suggesting that most actively managed funds match market performance before fees are taken into account, and underperform the market after fees are taken into account. This is not just the case in Bangladesh, but the rest of the world as well. As markets get more efficient, it becomes progressively harder to outperform a passively held market index, no matter how skilled the manager is (or perceive themselves to be). A number of famous research papers have shown that mutual funds in the US struggle to beat a passive market portfolio. The picture only gets worse the more efficient the market becomes.

Since all markets are on a constant journey towards better efficiency, including the capital markets of Bangladesh, the investing public needs to have an option to invest their capital in a minimum-fee passively managed portfolio that tracks the broad market (DSEX). This would give investors a very good investment alternative to existing mutual funds. By investing in an index fund, while investors would not be able to beat the market, they would be guaranteed not to underperform the market either.

Also, since all mutual fund managers charge management fees from their clients, it is essential that performance evaluation be done on a continuous basis to weed out the asset managers who do not perform well enough to justify their fees, from the very few asset managers who can justify the fees they charge to members of the investing public.

\section{References}

Apap, A., \& Collins, H. (1994). International Mutual Fund Performance: A Comparison. Managerial Finance, 20(4), 47-54. https://doi.org/10.1108/eb018471

Belgacem, S. B., \& Hellara, S. (2011). Predicting Tunisian mutual fund performance using dynamic panel data model. The Journal of Risk Finance, 12(3), 208-225. https://doi.org/10.1108/15265941111136950

Brinson, G., Hood, L., \& Beebower, G. (1995). Determinants of Portfolio Performance. Financial Analyst Journal, 5l(1), 133-138. https://doi.org/10.2469/faj.v51.n1.1869

Champagne, C., Karoui, A., \& Patel, S. (2018). Portfolio turnover activity and mutual fund performance. Managerial Finance, 44(3), 326-356. https://doi.org/10.1108/MF-01-2017-0003

Cheney, J., Atkinson, S., \& Bailey, B. (1992). International Mutual Fund Performance U.S. vs. U.K. Managerial Finance, 18(2), 39-48. https://doi.org/10.1108/eb018448

Ferreira, M., Keswani, A., Miguel, A., \& Ramos, S. (2013, April 1). The Determinants of Mutual Fund Performance: A Cross-Country Study. Review of Finance, 17(2), 483-525. https://doi.org/10.1093/rof/rfs013

Grinblatt, M., \& Titman, S. (1994, September). A Study of Monthly Mutual Fund Returns and Performance Evaluation Techniques. Journal of Financial and Quantitative Analysis, 29(3), 419-444. Https://doi.org/10.2307/2331338

Hili, J., Pace, D., \& Grima, S. (2016). Equity Mutual Fund Performance Evaluation: An Emerging Market Perspective. In S. Grima, \& F. Bezzina (Eds.), Contemporary Issues in Bank Financial Management (Vol. 97, pp. 93-132). Emerald Group Publishing Limited. https:/doi.org/10.1108/S1569-375920160000097009

Hou, T. C. T. (2012). Return persistence and investment timing decisions in Taiwanese domestic equity mutual funds. Managerial Finance, 38(9), 873-891. https://doi.org/10.1108/03074351211248207

Jensen, M. C. (1968). The performance of mutual funds in the period 1945-1964. The Journal of Finance, 23(2), 
389-416. https://doi.org/10.1111/j.1540-6261.1968.tb00815.x

Kaur, I. (2018). Mutual fund investor's behaviour towards information search and selection criteria: Do knowledge and perception about mutual funds matter?. Qualitative Research in Financial Markets, 10(4), 395-414. https://doi.org/10.1108/QRFM-09-2017-0084

Kiymaz, H. (2015). A performance evaluation of Chinese mutual funds. International Journal of Emerging Markets, 10(4), 820-836. https://doi.org/10.1108/JJoEM-09-2014-0136

Nguyen, A. N., Shahid, M. S., \& Kernohan, D. (2018). Investor confidence and mutual fund performance in emerging markets: Insights from India and Pakistan. Journal of Economic Studies, 45(6), 1288-1310. https://doi.org/10.1108/JES-07-2017-0175

Rao, Z. U. R., Tauni, M. Z., Iqbal, A., \& Umar, M. (2017). Emerging market mutual fund performance: Evidence for China. Journal of Asia Business Studies, 11(2), 167-187. https://doi.org/10.1108/JABS-10-2015-0176

Sharma, P., \& Paul, S. (2015). Testing the skill of mutual fund managers: Evidence from India. Managerial Finance, 41 (8), 806-824. https://doi.org/10.1108/MF-04-2014-0112

Sharpe, W. (1966). Mutual Fund Performance. The Journal of Business, 39(1), 119-138. https://doi.org/10.1086/294846

Treynor, J. L. (1965). How to rate management of investment funds. Harvard Business Review, 43(1), 63-75.

Treynor, J., \& Mazuy, K. (1966). Can mutual funds outguess the market? Harvard Business Review, 44(4), $131-136$

\section{Copyrights}

Copyright for this article is retained by the author(s), with first publication rights granted to the journal.

This is an open-access article distributed under the terms and conditions of the Creative Commons Attribution license (http://creativecommons.org/licenses/by/4.0/). 